\title{
TOMASZ KUBALICA
}

(Katowice)

\section{„PRZEWRÓT KANTA” W UJĘCIU RUDOLFA EUCKENA STUDIUM Z HISTORII PROBLEMU PRAWDY}

Z punktu widzenia historii filozofii istnieją wydarzenia, które odegrały szczególną rolę w rozwoju myśli filozoficznej. Do nich bez wątpienia należy „zwrot kopernikański" Immanuela Kanta (1724-1804). Należy postawić pytanie o historyczne znaczenie jego dokonania. $\mathrm{W}$ artykule zostanie podjęta próba ukazania, jak owo dokonanie było rozumiane przez laureata Nagrody Nobla w dziedzinie literatury - Rudolfa Christopha Euckena (1846-1926) ${ }^{1}$. Szczególnie doniosłe jest również zaprezentowanie - opisanych przez niego - konsekwencji „przewrotu” w historii filozofii. Ze względu na to, że całościowe ujęcie tego zagadnienia wykracza poza ramy tego tematu, szczególną uwagę skoncentrujemy jednak na znaczeniu „przewrotu" w historycznym rozwoju problemu prawdy.

Trudności związane z rozumieniem terminu „przewrót kopernikański” dostrzega Jan Garewicz, który stawia pytanie: czy ów zwrot oznacza rewolucje w metafizyce? ${ }^{2}$ Przewrót może oznaczać albo zmianę przedmiotu metafizyki, albo zmianę jej metod. Kant w tym kontekście explicite akcentuje zmianę sposobu myślenia, a zatem „przewrót” oznacza rewolucję metodologiczną, która wcale nie anuluje dotychczasowej problematyki filozoficznej. Ernst Cassirer w rozprawie

\footnotetext{
1 Zob. R. Eucken, Wielcy myśliciele $i$ ich poglady na życie. Zagadnienie życia ludzkości w rozwoju dziejowym od Platona do naszych dziejów. Tłum. A. Zieleńczyk, Lindenfeld, Warszawa 1914, s. 328. W kontekście historycznego znaczenia myśli Kanta Eucken mówi o „dokonanym przez Kanta przewrocie” („,...von Kant vollzogene Umwälzung”). Por. R. Eucken, Die Lebensanschauungen der grossen Denker. Eine Entwicklungsgeschichte des Lebensproblems der Menschheit von Plato bis zur Gegenwart. 19. Aufl., de Gruyter, Berlin 1930, s. 417.

2 Zob. J. Garewicz, Inaczej o rewolucji kopernikańskiej w filozofii, „Studia filozoficzne” 2 (1984), s. 122 i n. Por. także: A. J. Noras, Kant a neokantyzm badeński i marburski, Wyd. UŚ, Katowice 2000, s. 105.
} 
Kant a problem metafizyki szczególnie podkreśla, że w „przewrocie” nie chodzi o znalezienie nowej odpowiedzi na od dawna istniejące pytania, lecz o przesunięcie, które „zawiera nowe spojrzenie, nie tylko na to, co jest poznane lub możliwe do poznania, lecz na naturę i zadanie podstawowej funkcji samego myślenia" 3.

Zwykle poznanie wyobrażamy sobie jako zdobywanie wiedzy o rzeczywistości. W poznaniu podejmujemy starania, aby uzyskać wiedzę o otaczającym nas świecie. Nasze dążenia uznajemy za owocne wtedy, gdy jesteśmy przekonani, że nasze myśli są zgodne z poznawanymi przedmiotami. W ten sposób najprostsze wyobrażenie poznania zakłada, że w celu poznania przedmiotów umysł musi się do nich dostosowywać, a prawda w poznaniu polega na zgodności naszego wyobrażenia z zewnętrzną rzeczywistością.

Jednak w pewnym momencie rozwoju filozofii okazało się, że przez dostosowywanie się do przedmiotów nasz umysł nie jest w stanie uchwycić tego, co najważniejsze w poznaniu - nie potrafi poznać przyczyn otaczających nas zjawisk. Na przykład - jak wykazywał David Hume ${ }^{4}$ - dane uzyskane w doświadczeniu nie mówią między innymi nic o związku przyczynowym między poszczególnymi obserwowanymi przez nas zdarzeniami. W tym kontekście rodzi się pytanie, skąd czerpiemy naszą wiedzę na temat koniecznych powiązań między przyczyną a skutkiem?

Dla uzyskania zadowalającej odpowiedzi na tak postawione pytanie Kant zaproponował inne podejście do tego zagadnienia:

Dotychczas przyjmowano, że wszelkie nasze poznanie musi się dostosowywać do przedmiotów. Lecz wszelkie próby, by o nich przy pomocy pojęć orzec coś, co by poszerzyło poznanie nasze, obracały się przy takim założeniu wniwecz. Spróbujmy więc raz, czy się nam lepiej nie powiedzie przy rozwiązywaniu zadań metafizyki, jeśli przyjmiemy, że to przedmioty muszą się dostosowywać do naszego poznania ${ }^{5}$.

Ta zmiana - porównana przez samego Kanta do przełomu dokonanego przez Mikołaja Kopernika - polega na tym, że w jego ujęciu nie podmiot dostosowuje się do przedmiotu, lecz przeciwne - przedmiot do podmiotu ${ }^{6}$.

W ujęciu Euckena nie chodzi tylko o samą zmianę sposobu rozumienia relacji podmiot-przedmiot. Jego zdaniem „główny czyn Kanta” polega na rozwinię-

3 E. Cassirer, Kant a problem metafizyki. Uwagi na temat Heideggerowskiej interpretacji Kanta, „Przegląd Filozoficzny - Nowa Seria” 1 (2007), s. 313.

4 Zob. D. Hume, An Enquiry Concerning Human Understanding, The Project Gutenberg eBook, Oxford 1902, Section VII.

5 I. Kant, Krytyka czystego rozumu, tłum. R. Ingarden, PWN, Warszawa 1986, B XVI.

6 Zob. K. Dienst, Kopernkanische Wende; w: J. Ritter / K. Gründer // G. Gabriel (Hrsg.), Historisches Wörterbuch der Philosophie, Bd. 4, Schwabe, Basel 1976, s. 1094 i n. 
ciu i przeprowadzeniu we wszystkich konsekwencjach przedstawionej propozycji ${ }^{7}$. „Przewrót” na miarę Kopernika oznacza filozoficzną realizację nowej koncepcji poznania. Zasługą Kanta jest to, że nie poprzestał tylko na deklaracjach, lecz starannie uzasadnił swoje stanowisko. Przeprowadzony w Krytyce czystego rozumu dowód „przeobraża zupełnie tradycyjny obraz rzeczywistości” i polega między innymi na wykazaniu błędności dotychczasowych poglądów na temat relacji między podmiotem i światem ${ }^{8}$. W ten sposób Kant systematycznie toruję drogę nowego sposobu myślenia i życia człowieka.

Tak rozumiany „przewrót” posiadał szereg konsekwencji w różnych dziedzinach filozofii. Ze względu na ograniczone ramy niniejszego tekstu wymienimy tylko najważniejsze, a potem skoncentrujemy się przede wszystkim na konsekwencjach w teorii prawdy.

W pierwszej kolejności przełom dokonuje się w sposobie ujęcia kategorii przestrzeni i czasu, które wcześniej były ujmowane jako pewne „porządki przedmiotowe”, a teraz stały się „podmiotowymi formami oglądu”. Dzięki tym formom oglądu dusza człowieka potrafi uporządkować wrażenia, tak że dopiero dzięki nim możemy poznawać świat. Przełom w tej materii miał również zasadnicze znaczenie dla Kantowskiej filozofii matematyki.

Krytyka Kanta - jak już częściowo zostało stwierdzone - objęła jednak przede wszystkim pojęcie rzeczy i związku przyczynowego:

Rozsądek nasz - jak pisał Eucken - wytwarza pojęcie rzeczy, żeby wrażeniom, w ogóle rozproszonym, dać oparcie i połączyć je w całość; wszelkie związki zjawisk również nie stanowią porządku, ani objawów świata zewnętrznego, lecz są naszym własnym dziełem ${ }^{9}$.

Kant wykazał, że nasze odczucia stają się doświadczeniem dopiero dzięki myśleniu. Podważył w ten sposób podstawowe założenie materializmu, który przyjmuje, że poza nami znajdujemy gotowe pierwiastki i związki zjawisk. Zmiana w tym zakresie mała istotne znaczenie dla filozoficznej dyskusji nad zagadnieniem realności w obrębie epistemologii i ontologii.

Poważne konsekwencje ma również „przewrót” w dziedzinie moralności ${ }^{10}$, gdzie otwiera i ukazuje podmiotowi możliwość samodzielnego działania i tworzenia świata własnymi siłami. Autonomia działania nie oznacza jednak braku zasad,

\footnotetext{
7 R. Eucken: Wielcy myśliciele..., wyd. cyt., s. 327-328.

8 Zob. tamże, s. 328.

9 Tamże, s. 329. Jednak prawdziwy przełom wiąże się z konsekwencjami dla udzielenia odpowiedzi na pytania ostateczne. Konsekwencją przewrotu jest przyjęcie, że nasze poznanie w zakresie spraw ostatecznych (duszy, wszechświata i Boga) może zawierać się tylko w obrębie naszego rozumu.

10 Zob. tamże, s. 332 i n.
} 
lecz przeciwnie, musi opierać się na „wewnętrznym” imperatywie kategorycznym. Jednocześnie podstawowe znaczenie dla moralności uzyskuje idea wolności woli ${ }^{11}$. Na gruncie moralności realne znaczenie odzyskują - odrzucone przez rozum teoretyczny - idee istnienia Boga oraz nieśmiertelności duszy. W ten sposób „przewrót” dokonuje się w etyce. O podobnym „przewrocie” można mówić w estetyce, gdzie Kant podkreślił podmiotowy charakter piękna przez zaakcentowanie pojęcia wzniosłości ${ }^{12}$.

Jednak najbardziej doniosły ze względu na konsekwencje „przewrót” dokonał się w dziedzinie teorii prawdy. Eucken przedstawia to zagadnienie w wydanym w 1908 roku dziele pt. Einführung in eine Philosophie des Geisteslebens, gdzie filozofia - podobnie jak wcześniej u Wilhelma Windelbanda (1848-1915) - zostaje potraktowana jako wiecznie żywy problem ${ }^{13}$. Zaś do istoty filozofii należy problem prawdy.

Zdaniem Euckena, człowiek jako istota wewnętrznie ograniczona w swym dążeniu do prawdy pragnie przezwyciężyć swą ograniczoność przez wyjście od tego co podmiotowe (Zuständlichen) do tego, co przedmiotowe. W tym miejscu ujawnia się zasadnicze przeciwieństwo, jakie zachodzi między dążeniem do prawdy a dążeniem do szczęścia ${ }^{14}$. Przeciwieństwo to polega na tym, że w dążeniu do prawdy - zupełnie inaczej niż w dążeniu do szczęścia - człowiek musi odłożyć na bok swoje wewnętrzne odczucia (Befinden). Zasadnicze pytanie, które stawia Eucken dotyczy tego, jak dalece jest możliwe zbliżenie między tymi dążeniami? Czy można oba cele ludzkich dążeń przemienić w dwa bieguny jednego życia?

Potocznie prawda - jak już zostało stwierdzone - oznacza zgodność naszego obrazu rzeczywistości ze stanem fatycznym. W takim ujęciu prawda jest rozumiana jako zgodność naszego przedstawienia z przedmiotami (adaequatio intelectus et rei). Jednak, gdy człowiek próbuje zrozumieć świat i swój stosunek do niego, to musi wyjść poza takie rozumienie prawdy ${ }^{15}$. Człowiek rozwija niezależny od świata rzeczy krąg własnych myśli, których nie można porównać z niczym innym. W takiej sytuacji pojęcie prawdy rozumianej jako odbicie rzeczywistości, jako zgodność naszego przedstawienia ze światem rzeczy, wymaga gruntownego przemyślenia. Dla Euckena nieprzystawalność potocznego rozumienia prawdy do świata myśli wynika z rozwoju samodzielnego życia wewnętrznego, czyli rozwoju

11 Zob. A. J. Noras, Nicolaia Hartmanna koncepcja wolności woli, Wyd. UŚ, Katowice 1998, s. $57 \mathrm{i} \mathrm{n.}$

12 Zob. tamże, s. 337 i n.

13 Zob. R. Eucken, Einführung in eine Philosophie des Geisteslebens, Quelle \& Mener, Leipzig 1908 , s. V.

14 Zob. tamże, s. 131 i n.

15 Zob. tamże, s. 133-134. Por. J. Woleński, Epistemologia - poznanie - prawda - wiedza realizm, PWN, Warszawa 2005, s. 88 i n. 
kultury. Rozwój ten wprowadza zasadniczy rozziew między nami a światem. Od starożytności praca filozofii polega - jego zdaniem - na poszukiwaniu drogi przezwyciężenia tej sprzeczności.

Każda epoka ma swój charakterystyczny sposób rozwiązywania tego problemu. Czasy starożytne charakteryzuje - zdaniem Euckena - „naiwna antropomorfizacja świata", która przypisuje wszystkim formom bytu atrybuty życia i myśli ${ }^{16}$. Dlatego prawda w ujęciu klasycznym polega ciągle na zgodności podmiotu z obiektem, myślenia z bytem. Dążenie zaś do prawdy polega na przyswojeniu całej prawdy o rzeczach niezależnie od przepaści, która ma miejsce między światem myśli a światem rzeczy.

Jednak z biegiem czasu pogłębia się świadomość przepaści między człowiekiem i światem, co rzutuje na konieczność innego niż klasyczne ujęcia dążenia do prawdy. Zdaniem Euckena, wspomniana przepaść została ujawniona już w starożytności przez Plotyna, który odkrył byt w myśleniu i uczynił go duszą całej rzeczywistości ${ }^{17}$.

Świadomość przepaści została pogłębiona przez chrześcijaństwo, które ponadto istotnie zmieniło sposób rozumienia dążenia do prawdy; od tej pory pragnienie osiągnięcia prawdy stało się nie tyle aktem wiedzy, co aktem wiary na drodze do zbawienia. Jednak taki sposób ujęcia doprowadził do dodatkowych problemów z właściwym ujęciem relacji wiedzy oraz wiary.

Czasy nowożytne uwolniły filozofię od problemów z wiarą, ale jednocześnie na nowo odrodziło się pytanie, gdzie należy szukać prawdy ${ }^{18}$. Odpowiedź nasunęła się sama. Jeżeli prawdy nie można znaleźć w zgodności z rzeczywistością, zatem należy jej poszukiwać w sobie samym. W ten sposób rozum zajął miejsce świata i Boga. W tym okresie historii dążenia do prawdy przewage uzyskuje pogląd, aby myślenie uznawać za źródłową twórczość, która prowadzi wolnego człowieka do prawdy. W takim ujęciu roli myślenia Eucken wyróżnia trzy fazy: oświecenie (Kartezjusz, B. Spinoza, G. W. Leibniz), filozofia krytyczna (I. Kant) oraz konstruktywistyczna spekulacja (J. G. Fichte, F. W. J. Schelling i G. W. F. Hegel).

Charakterystyczne dla oświecenia wyjście od myślącego podmiotu nie oznacza zdaniem Euckena końca w dążeniu do prawdy ${ }^{19}$. Przeciwnie, w tym okresie treści prawdy poszukuje się w ,ideach wrodzonych” oraz ,wiecznych prawdach” 20. Powszechna ważność prawdy zostaje, wraz z królestwem rozumu, zagwarantowana

16 Zob. R. Eucken, Einführung in eine Philosophie..., wyd. cyt., s. 133-134.

17 Zob. tamże, s. 139 i n.

18 Zob. tamże, s. $144 \mathrm{i} \mathrm{n}$.

19 Zob. tamże, s. 146 i n.

20 Zob. G. W. Leibniz, Nowe rozważania dotyczace rozumu ludzkiego, tłum. I. Dąmbska. Antyk, Kety 2001, s. 342 i n. 
w rozwoju prawd wiecznych, zaś jednostka ludzka dochodzi do niej w wyniku pracy intelektu. Jednak również tutaj u podstaw leży przekonanie, że rozum nie jest tylko rzeczą człowieka, lecz przynależy całemu światu, ponieważ cały wszechświat jest ugruntowany w rozumie boskim. Tylko w ten sposób to, co poznaje rozum człowieka może być w sposób niczym nieograniczony dla niego ważne. Partycypacja w boskim zamyśle jest możliwa dopiero wtedy, gdy nasza praca intelektualna uwalnia nas od wpływu ludzkich stanów (psychicznych) i opiera się wyłącznie na wewnętrznej konieczności myśli. Dlatego pierwszym warunkiem prawdy jest skromność człowieka i świadome podporządkowanie się konieczności wynikającej z tej rzeczy. Tylko czyste myślenie wolne od małostkowości może przenieść nas do wiecznego i nieskończonego życia świata.

Ten nowy sposób ujęcia posiada doniosłe konsekwencje dla samego pojęcia prawdy. Spinoza w miejsce klasycznego pojęcia zgodności postuluje paralelność myśli i rzeczy ${ }^{21}$. Każde zjawisko jest przejawem lub przymiotem jednej i tej samej najwyższej substancji. Rozwiązanie zaproponowane przez Spinozę wiąże się jednak z pewnymi problemami: który z atrybutów jest podstawowy, w jaki sposób jeden atrybut może służyć do oceny drugiego, czy Spinoza nie za bardzo ogranicza życie człowieka tylko do aktywności intelektualnej?

Zdaniem Euckena dopiero w filozofii Kanta stało się zupełnie jasne, że prawda nie może polegać na zgodności myśli z danym na zewnątrz bytem ${ }^{22}$. Prawda musi być zupełnie inaczej rozumiana. W myśli Kanta zachodzi tutaj odwrócenie stosunku myśli i bytu: nie myśl kieruje się do bytu, lecz - byt do myśli. Jeżeli nasza wiedza o rzeczywistości zależy od form naszej duchowej konstytucji, to tym samym prawda nie polega na poznaniu rzeczy, lecz na samopoznaniu ludzkiego ducha. Takie samopoznanie dostarcza nam nieporównywalnie bogatszą treść oraz nowy transcendentalny sposób prowadzenia rozważań, który zasadniczo różni się od metody empiryczno-psychologicznej. Człowiek w dążeniu do prawdy nie wychodzi poza siebie, lecz pozostaje we własnym kręgu myśli.

Eucken doszukuje się istoty „przewrotu” w odmiennym zarówno od potocznego, jak i od klasycznego sposobie rozmienia prawdy:

Dopiero Kant wykazuje zupełnie jasno i przekonywająco, że jest to zupełny nonsens chcieć poznać rzecz istniejącą niezależnie od nas, taką jaka ona jest ${ }^{23}$.

Argumentacja jest następująca. Próba poznania rzeczy niezależnych od nas musi zakończyć się niepowodzeniem, ponieważ przez to, że staną się dla nas poznawalne musiałyby się zmienić i przestać być niezależne od nas. Ponadto, ze

21 Zob. R. Eucken, Einführung in eine Philosophie..., wyd. cyt., s. 148 i n.

22 Zob. tamże, s. 149 i n.

23 R. Eucken, Wielcy myśliciele..., wyd. cyt., s. 327. 
względu na brak możliwości porównania rzeczy i naszych wyobrażeń, nie można stwierdzić zachodzącej między nimi zgodności. Dodatkowo powstaje kwestia, jak osiągnąć istotną dla prawdziwego poznania powszechność i konieczność. W ten sposób założenie o zgodności myśli i rzeczy prowadzi nieuchronnie do zanegowania możliwości poznania, czego z przyczyn oczywistych należy unikać.

W tym ujęciu Eucken zbliża się - nie po raz pierwszy i po raz ostatni - do poglądów szkoły badeńskiej na istotę „przewrotu kopernikańskiego” i podobnie jak oni dostrzega jego poważne konsekwencje dla teorii prawdy. Zarówno Heinrich Rickert, jak i Emil Lask podkreślają, że zmiana sposobu myślenia dokonana przez „przewrót” polega na obaleniu teorii odbicia ${ }^{24}$, która stanowi podstawowe założenie opartego na zgodności rozumienia prawdy. Różnica między nimi polega jednak na tym, że odrzucenie teorii odbicia doprowadziło neokantystów do formalizmu w filozofii, za co byli krytykowani przez przedstawicieli filozofii życia.

Jak już zostało stwierdzone, sam Kant swoją hipotezę sposobu rozumienia poznania porównał do przewrotu dokonanego przez Mikołaja Kopernika, który przyjął, że to nie ciała niebieskie obracają się wokół nas, lecz przeciwnie to my obracamy się względem nich. Podobieństwo między dokonaniem Kanta a dokonaniem Kopernika nie jest tylko i wyłącznie metaforyczne, lecz zawiera - jak zauważa Eucken - również porównanie ich czynów pod względem treści: w obu przypadkach zajmuje się perspektywą nie rzeczy, lecz widza. Istotną z naszego punktu widzenia konsekwencją „przewrotu” jest to, że prawda jest ważna nie dla rzeczy, lecz wyłącznie dla nas:

Prawdę możemy ocalić tylko w ten sposób, że ograniczymy ją do jej własnego zakresu i wyrzekniemy się wszelakiego jej znaczenia poza nim ${ }^{25}$.

A zatem nie ma prawdy zupełnie niezależnej od podmiotu. W ten sposób prawda zostaje uwarunkowana przez dwa czynniki: z jednej strony przez czynnik podmiotowy - formy poznania. Z drugiej strony jednak człowiek potrzebuje w poznaniu pewnej inspiracji zewnętrznej. A zatem istotny pozostaje również drugi czynnik poznania - dana z zewnątrz treść:

Treść ta jest nam potrzebna koniecznie do każdego poznania; co zaś z nią czynimy, to już zależy od nas; budowy świata, spójnego doświadczenia nie znajdujemy w stanie gotowym, lecz dokonywamy tego z siebie; porządek i prawidłowość zjawisk, to, co właśnie nazywamy przyrodą, wyprowadzamy sami, nie znaleźlibyśmy ich tam, gdybyśmy ich tam nie włożyli ${ }^{26}$.

24 Zob. A. J. Noras, Kant a neokantyzm..., wyd. cyt., s. 181 i n.

25 R. Eucken, Wielcy myśliciele..., wyd. cyt., s. 328.

26 Tamże. 
A zatem, można powiedzieć, że w konsekwencji prawa natury nie pochodzą od przyrody, lecz zostają jej „przypisane” przez intelekt.

Dotychczasowe znaczenie i wartość prawdy wynikała z tego, że była ona niezależna od nas i istniała nawet wbrew nam. Kant pozbawił nas raz na zawsze pojęcia prawdy w dawnym znaczeniu. Jednocześnie dał nam on „mikroskopową możliwość badania”, w której pozornie proste czynności poznawcze wykazują znacznie subtelniejszą i bogatszą strukturę. Kantowskie znaczenie polega zatem również na tym, iż przeprowadził jeszcze bardziej szczegółowe dystynkcje, niż ktokolwiek i kiedykolwiek przedtem. Z drugiej strony jednak Kant dokonuje nie tylko rozróżnień, lecz potrafi również rozdzielone części łączyć z powrotem w całości i tworzy „największe dzieło architektoniczne w dziejach filozofii”.

Najistotniejszą konsekwencją „przewrotu” dla sposobu rozumienia prawdy jest relatywizacja pojęcia prawdy w dziedzinie filozofii teoretycznej ${ }^{27}$. Inaczej jest w dziedzinie rozumu praktycznego, gdzie od podmiotu wymaga się twórczej aktywności w dążeniu do pełnej prawdy. Dla Kanta świat w wymiarze ostatecznym posiada sens moralny i dlatego człowiek uzyskuje wielkość i godność dopiero przez dobrowolny udział w powszechnie obowiązującej - nie poddanej relatywizacji prawdzie. W ten sposób nie można zarzucić Kantowi odejścia od rzeczywistości i poznania natury świata przez człowieka. Te wszystkie elementy znajdują swoje miejsce w myśli Kanta, chociaż uzyskują zupełnie inny sens.

Zdaniem Euckena Kant rozpoczyna nową epokę rozumienia dążenia do prawdy. Ograniczenia dotychczasowego sposobu rozumienia pojęcia prawdy stały się oczywiste. W miejsce powiązania człowieka z otaczającym światem otwarła się nowa perspektywa świata zawartego we własnej istocie. Ugruntowanie dążenia do prawdy w moralności sprawia, że jest ono prostsze, pewniejsze i bardziej owocne. Eucken ujmuje to w następujący sposób:

Tutaj zostaje dokonane zasadnicze uwolnienie dążenia do prawdy od wszelkiego czystego intelektualizmu a tym samym pogłębione również pojęcie prawdy ${ }^{28}$.

Jednakże zaproponowany przez Kanta nowy sposób ujęcia pojęcia prawdy generuje kolejne problemy, co ujawnia się w dyskusji nad właściwą interpretacją jego myśli ${ }^{29}$. Eucken wskazuje następujące trudności: czy można ustanowić podmiot wewnętrzną stroną życia i jednocześnie powiązać w poznaniu z nieprzejrzystym światem? Czy można w moralności uznawać dziedzinę prawdy absolutnej? Jak

\footnotetext{
27 Zob. R. Eucken, Einführung..., wyd. cyt., s. 150.

28 Es wird hier eine gründliche Befreiung des Wahrheitsstrebens von allem bloßen Intellektualismus vollzogen und damit auch der Begriff der Wahrheit vertieft, tamże, s. 151.

29 Zob. tamże, s. 151-152.
} 
pogodzić rozum praktyczny z rozumem teoretycznym? Z całą pewnością Kant nie rozwiązał wszystkich problemów - przeciwnie wywołał potężny ruch i stał się zarzewiem nowych dyskusji.

W poszukiwaniu odpowiedzi na problemy zawarte w filozofii Kanta nurt filozoficznej spekulacji, który zainicjował J. G. Fichte, uzyskał pełnię w filozofii G. W. F. Hegla. Myśl w dialektycznym procesie znoszenia wewnętrznych sprzeczności wykroczyła poza sam podmiot i stała się siłą napędową historii. Człowiek przez odrzucenie ograniczonych poglądów i samowolnych dążeń zmierza do pełnej i absolutnej prawdy. Jednak jako rozwiązanie problemu prawdy propozycja ta zawiera ryzyko niczym nie ograniczonego subiektywizmu, w którym umyka wspólna dla wszystkich prawda.

W ten sposób problem prawdy znalazł się współcześnie ponownie w trudnym położeniu. Z tego powodu pojawiają się próby powrotu do wyjściowego, naiwnego i pozbawionego metafizyki rozumienia prawdy ${ }^{30}$. W taki sposób postępuje pozytywizm, który sprowadza poznanie do stwierdzania i opisywania relacji między rzeczami. Podobnie postępuje pragmatyzm, który traktuje prawdę jako środek do osiągania skuteczności w działaniu. Jednak problem z tego rodzaju podejściem polega na tym, że, o ile można odnosić się do natury jako czegoś zewnętrznego, to nie można w ten sposób postępować w stosunku do innych ludzi oraz do samego siebie. Zasługa pragmatyzmu było uwolnienie problemu prawdy z dotychczasowej izolacji i ścisłe powiązanie jej z całością życia ${ }^{31}$. Jednak podporządkowanie prawdy kategorii użyteczności jest zbyt ograniczające, ponieważ prowadzi do panowania przeciętności. Eucken poszukuje takiego ujęcia dążenia do prawdy, które nie będzie obniżać naczelnej wartości życia. Jego zdaniem dążenie do prawdy opiera się na pragnieniu dotarcia do istoty życia ${ }^{32}$. Tylko takie ujęcie dążenia do prawdy nie stawia go w opozycji w stosunku do dążenia do szczęścia.

Stosunek Euckena do Kanta pozostaje krytyczny. Jego zastrzeżenia dotyczą relacji między podmiotem a jednostką ludzką: jak jednostka staje się podmiotem? Drugi zarzut dotyczy zasadniczego przeciwieństwa, jakie zachodzi między rozumem teoretycznym a rozumem praktycznym; tak przeprowadzony podział nie pozwala ująć w dostatecznym stopniu możliwości człowieka jako całości. Kolejny zarzut dotyczy Kantowskiego formalizmu. Eucken stawia pytanie:

Czyż w istocie forma wyczerpuje nasze zdolności duchowe, i czyż nawet w najwyższym rozwoju wytwarza ona pełną życia rzeczywistość? ${ }^{33}$

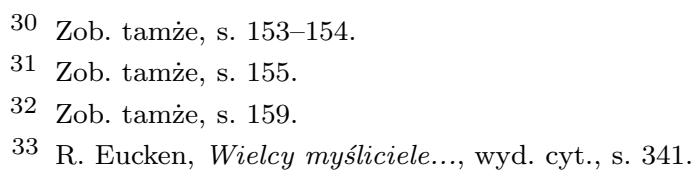


W ten sposób etyka Kanta pozostaje tylko etyką prawa, a nie etyką „potęi przenikającej życie”. Kant ujmuje myśli jako gotowe formy i nie uwzględnia ich dynamicznego charakteru. Wymienione zastrzeżenia stały się powodem i inspiracją do dalszego rozwoju. Eucken podpisuje się pod neokantowskim hasłem „z powrotem do Kanta", które oznacza dla niego trwanie przy Kancie, oderwanie się od Kanta i wyjście poza Kanta ${ }^{34}$.

Eucken dochodzi jednak do wniosku, że: „Kantowska teoria poznania nie tylko więc dużo odebrała, ale też wiele dała” ${ }^{35}$. Między innymi właśnie „przewrót" doprowadził do powstania filozofii opartej na nowej metodzie - metodzie transcendentalnej ${ }^{36}$. Nowa filozofia transcendentalna, choć koncentruje się na podmiocie, nie pyta jak jednostka ludzka dochodzi do pewnych zdobyczy takich jak nauka, moralność etc, lecz przyjmuje owe zdobycze za oczywiste i rozważa, jak one są możliwe w obrębie życia duchowego. W ten sposób wyznaczone zostało nowe zadanie filozofii, które polega na wykrywaniu tkwiących w ludzkim duchu w istocie kreatywnych możliwości poznawania świata. Takie poznanie stanowi jednocześnie samopoznanie człowieka.

Na zakończenie można postawić pytanie, jakie są konsekwencje „przewrotu” dla naszego życia codziennego? Czy w związku z ustaleniami dokonanymi przez Kanta, musimy zmienić coś w naszym życiu? Otóż, nie musimy niczego zmieniać. Tak jak po przewrocie dokonanym przez Kopernika nadal wschód słońca nazywamy „wschodem” a zachód słońca - „zachodem”, chociaż słońce jako takie ani nie wschodzi, ani nie zachodzi. Podobnie, również po „przewrocie” dokonanym przez Kanta w sposobie rozumienia prawdy nie musimy niczego zmieniać w naszych myślowych przyzwyczajeniach i nadal możemy mówić o prawdzie jako zgodności naszego poznania z przedmiotem, chociaż właściwie rzecz ujmując ów przedmiot jest konstruowany przez nas, a prawda ostatecznie polega na zgodności z prawami intelektu i rozumu.

\footnotetext{
34 Zob. tamże, s. 341.

35 Tamże, s. 331.

36 Zob. tamże, s. 332.
} 